\title{
Molecular tools for identification and classification of Myxozoan parasites (Cnidaria: Myxosporea) in India: Current status
}

\author{
Abhishek Gupta \\ Molecular Taxonomy Laboratory, Department of Zoology, Chaudhary Charan Singh University, \\ Meerut-250004 (U. P.), India \\ Anshu Chaudhary \\ Molecular Taxonomy Laboratory, Department of Zoology, Chaudhary Charan Singh University, \\ Meerut-250004 (U. P.), India \\ Anju Tyagi \\ Molecular Taxonomy Laboratory, Department of Zoology, Chaudhary Charan Singh University, \\ Meerut-250004 (U. P.), India \\ Bindu Sharma* \\ Molecular Taxonomy Laboratory, Department of Zoology, Chaudhary Charan Singh University, \\ Meerut-250004 (U. P.), India \\ Hridaya S. Singh \\ Molecular Taxonomy Laboratory, Department of Zoology, Chaudhary Charan Singh University, \\ Meerut-250004 (U. P.), India \\ *Corresponding author. Email: dr.bindusharmazoology@gmail.com
}

\section{How to Cite}

Gupta, A. et al. (2021). Molecular tools for identification and classification of Myxozoan parasites (Cnidaria: Myxosporea) in India: Current status.. Journal of Applied and Natural Science, 13(1): 51 - 58. https://doi.org/10.31018/jans.v13i1.2451

\section{Abstract}

A substantial literature on myxosporea has been published to date using morphological characters and specificity of host tissue. Currently, there are some 2400 nominal species of myxosporea classified to 17 families and 64 genera. Approximately 300 species have been described from India and most of them have been described solely on the basis of morphological characteristics. Molecular markers like small subunit ribosomal (SSU) and large subunit ribosomal (LSU) DNA have been used worldwide for the identification and validation of fish myxosporeans. Maximum likelihood phylogenetic tree based on SSU rDNA sequences was used to study the phylogenetic relationship among myxosporeans infecting Indian fishes. Myxospore phylogenies disagree with traditional spore-based classification systems, probably due to extreme plasticity in myxospores morphologies that have resulted in extensive convergence. Morphological similarities exist among myxosporea that encounter several problems in categorizing them. That's why present-day research has shifted to molecular techniques for identification and correct systematics of myxosporeans. Molecular studies of myxozoans in India are still scarce and in infancy. To address persisting taxonomic and phylogenetic discrepancies, validation of these species by molecular tools is needed, because earlier species were reported only on the basis of morphological data. Therefore, the present study has summarized existing molecular data and current status of molecular taxonomy of myxosporeans parasitizing fresh and marine water fishes of India along with the approaches of myxozoan phylogenetics and information about the molecular markers, their interpretation in the identification of myxozoans parasitizing fishes.
\end{abstract}

Keywords: Myxosporea, Systematics, Fish parasites, Molecular marker, Phylogenetic analysis, Validation

\section{INTRODUCTION}

Myxosporea representing about $20 \%$ of described cnidarian species evolved as endoparasites and are radiated into a diverse range of morphologically different parasitic species (Fiala et al., 2015). Myxosporean parasites are well known for infecting fishes, both freshwa- ter as well as marine. For the first time in freshwater fish, myxozoan cysts were reported in the musculature of Coregonus fera from a lake in Geneva by Jurine in 1925 , while in India the work on myxozoan was initiated by Bosanquet in 1910 (Abdel-Gaber et al., 2017). A number of myxosporean species have also been described from annelids, amphibians, reptiles and birds. 
More than 2400 species belonging to 64 genera have been reported worldwide (Lom and Dykova, 2006). Studies on myxosporean parasites of fishes in India have shown that among different genera, only Myxobolus, Henneguya and Thelohanellus have been frequently described (Kalavati and Nandi, 2007; Kaur and Singh, 2012; Singh and Kaur, 2012; Kaur, 2014). Approximately 300 species of myxobolids have been reported till date from India (Kaur and Singh, 2012). Myxobolids fauna has been investigated by a limited number of researchers in India (Gupta et al., 2018; Chaudhary et al., 2019). Many of the reported species have been identified and described solely on the basis of spore morphology. The end of the 20th century laid the foundation of the molecular era, and the controversies between the traditional spore-based taxonomy of myxosporeans and the rDNA-based phylogenies started.

It is true that myxospore morphology remains important, as it is the fundamental diagnostic feature for identification, but great discrepancies were found between the phylogenetic relationships of myxospores inferred from spore-based myxobolids taxonomy (Fiala and Bartosova, 2010). Morphological tools have failed to identify congeneric species, like those found in same infection site in different fishes with only minor differences in their morphology and structures of spores ( $\mathrm{Ye}$ et al., 2017). These problems have been resolved with the help of molecular studies (Smothers et al., 1994). Smothers et al. (1994) used first time ribosomal DNA (rDNA) sequence to explore the phylogenetic position of the Myxozoa within Metazoa. After that, the use of molecular data started to explain the phylogenetic relationships within myxozoans. Different molecular markers, particularly small subunit ribosomal DNA (SSU rDNA), have been used most frequently to identify and study phylogeny of myxosporean parasites of fishes worldwide. Gradual enrichment of rDNA data on myxosporean species brought about the elimination of some genera and families. At present, a consolidated methodology consisting of spore morphology, site of sporulation, tissue as well as host explicitness and molecular characteristics has been generally suggested and acknowledged for taxonomic evaluation of myxosporean species and for segregation of species with morphological resemblance (Holzer et al., 2004).

Molecular characterization has been broadly accepted as a significant criterion for taxonomy and discrimination of congeneric myxosporean species (Bartosova et al., 2013). There are certain ambiguities in the systematics of these parasites that need to be resolved for future taxonomists working in this field. Therefore, the aim of the present review is to summarize existing molecular data of myxosporea parasitizing the fishes of India.

\section{USE OF MOLECULAR MARKERS IN MYXOZOAN SYSTEMATICS}

In cnidarian evolution, myxosporea derived from a common ancestor and exhibited an ancient cnidarian lineage (Kent et al., 2001). Conservative phylogenetic markers, like small and large subunit ribosomal DNA gene, are required to reconstruct myxosporean diversification. Nowadays, SSU rDNA sequences are most important in the systematics of myxosporea and have been used frequently to understand their phylogeny (Fiala, 2006; Evans et al., 2010; Zhao et al., 2013; Naldoni et al., 2018), due to heterogeneous nature of its conserved as well as variable regions that facilitate accurate differentiation of myxosporean parasites at different taxon levels. The conserved regions of the molecular marker are helpful in DNA sequences multiple alignments and also facilitate the development of primers for amplification purpose while variable regions give information about the diversification process. Studies proved that this gene evolved very rapidly because SSU rDNA molecular marker of myxosporean fauna shows high substitution rates in their variable regions (Saulnier et al., 1999; Hartikainen et al., 2014).

Large subunit ribosomal DNA (LSU rDNA) sequences have been used for myxozoan phylogenetics due to their conserved and variable regions. LSU rDNA molecular marker has also been used in congruence with SSU rDNA based phylogenetic analysis and sometimes used in combination for particular inferences (Whipps and Kent, 2006). According to several workers (Fiala 2006; Bartošová et al., 2009; Fiala and Bartosova, 2010), the LSU rDNA sequences are more reliable than SSU rDNA for myxobolids phylogeny with which we also agree. However, myxosporean SSU rDNA sequences are more in numbers than LSU rDNA in National Centre of Biotechnology Information (NCBI) database, being the first choice of marker for those working in the analysis of myxozoan phylogenetics. At intraspecies level, the internal transcribed spacer region 1 (ITS 1) is found to be more reliable than SSU rDNA to find the similarity or dissimilarity and relatedness between congeneric myxosporean species (Andree et al., 1999). Phylogenetic analysis of myxosporean species on the basis of elongation factor (EF2) genes was also found reliable with those based on ribosomal DNA (Fiala and Bartosova, 2010). Molecular markers such as HSP70, mitochondrial gene 12S, COX -1 and some protein-coding genes like rad51 and rpl23a have also been used for molecular identification of myxosporean parasites (Whipps et al., 2004).

\section{Molecular data of Myxozoan parasites from India}

According to Kalavati and Nandi (2007), approximately 300 species have been described from the Indian subcontinent and most of them have been described solely on the basis of morphological characteristics. Myx- 
obolids parasites possess several morphological features that can be used as a distinguishing feature among them, but several genera demonstrate similar morphological characteristics. Therefore, in myxobolids taxonomy, the molecular analysis should be in congruence with morphological characteristics that can verify and offer great independent evidence relevant for phylogenetic based systematics. Several studies show that phylogenetic analysis with some molecular markers more reliable and consistent over morphological taxonomic features (Palenzuela et al., 2002; Gupta et al., 2018; Kosakyan et al., 2019). In India, identification of myxosporean parasites through molecular tools is at its initial stage as several workers have reported these parasites using morphological classical taxonomic tools. GeneBank database of NCBI for Indian myxobolids molecular data comprises of only 66 sequences of $18 \mathrm{~S}$ rDNA belonging to 40 species of myxobolids (Table 1).

Out of total 66 sequences submitted to NCBI, 32 sequences belong to genus Myxobolus, followed by genus Thelohanellus with 23 sequences, 04 sequences belonging to Ceratomyxa, 03 sequences belonging to Henneguya, 02 sequences belonging to Chloromyxum and one each from genus Ortholinea and Zschokkella respectively. In India, studies on these groups of cnidarian parasites on the basis of molecular taxonomy has been done by a very limited number of researchers mainly from West Bengal, Uttar Pradesh, Kerala and Punjab (Singh and Kaur, 2012; Kaur, 2014; Rajesh et al., 2014; Abraham et al., 2015; Szekely et al., 2015). Due to very few rDNA sequences of Indian myxosporean, it puts a question mark on the taxonomy of these parasites in India. Szekely et al. (2015) analyzed $18 S$ rDNA gene sequences of 05 different Myxobolus species infecting carp fishes from Meerut, Uttar Pradesh. Chaudhary et al. $(2017,2018,2019)$ reported 04 myxozoan species from catfishes belonging to genus Henneguya and Myxobolus based on molecular taxonomy. Similarly from Meerut, (Uttar Pradesh) Gupta et al. (2018) also analyzed three isolates of Thelohanellus wallagoi infecting different organs of freshwater fish Wallago attu viz; gills, kidney and intestine, and found that all the sequences were similar to each other. All these researchers validated the status of the reported parasites after many years of its original description. Kaur and Attri (2015), Kaur and Gupta (2017a, b), Gupta and Kaur (2017) and Kaur et al. (2014) investigated molecular characterization of 04 species of Thelohanellus and 01 species of Henneguya based on $18 \mathrm{~S}$ rDNA gene in Punjab. Abraham et al. (2015) from West Bengal and Banerjee et al. (2015a, b, 2017) analyzed $18 S$ rDNA gene sequences of 04 myxozoan species belonging to genus Myxobolus and Thelohanellus. Sanil et al. (2017) and Chandran et al. (2018, 2020) from Kerala analyzed 18S rDNA gene sequences of 03 myxozoan species belonging to genus Chloromyxum and Ortholinea (Table 1).

Myxosporea systematics demands, extensive work on molecular taxonomy of these parasites. Revisions of myxobolids taxonomy are also needed in accordance with existing paraphylectic and polyphylectic genera (Anjan et al., 2014; Abidi et al., 2015; Fariya et al., 2020). Molecular markers like SSU and LSU have a tremendous role in the systematics of myxobolids parasites because of many congeneric species' presence, having highest morphological similarities.

\section{Phylogenetic analysis of Myxozoans sequenced from India}

The phylogenetic analysis based on SSU rDNA sequences conducted with MEGA X (Kumar et al., 2016) in the present study revealed discrepancies between spore-based classification system and phylogenybased schemes. The phylogenetic analysis supported a split of myxosporeans into two main lineages separating freshwater species (freshwater clade) and marine species (marine clade) (Fig. 1). The freshwater clade split into two distinct lineages (Myxobolus clade and Thelohanellus clade). Marine clade consisted of Ceratomyxa spp. Six of seven genera studied (Myxobolus, Henneguya, Thelohanellus, Chloromyxum, Ortholinea, Zschokkella) are paraphyletic. Ceratomyxa is the only monophyletic genera and molecular phylogeny based on SSU data of such groups belongs to myxosporea showed consistency with traditional, morphology-based classification. Representatives of genus Myxobolus were intermixed with morphologically dissimilar Henneguya spp. The species of genus Henneguya probably arose from Myxobolus ancestors several times in myxosporean evolution. The caudal appendages do not represent a valid character for the distinction of genera Myxobolus and Henneguya. The freshwater clade is composed of myxosporean infecting freshwater fishes but includes two exceptional species, Chloromyxum argusi and Ortholinea scatophagi from Scatophagus argus. Both species are found to infect coastal fish in a marine environment that clusters with freshwater myxosporeans. It seems that the common ancestor of marine Chloromyxum spp. and Ortholinea spp. was the freshwater myxosporean. The position of such myxosporean species from coastal fish among the clade of freshwater species seems logical since hosts of these species often enter estuaries and rivers. It is unexpected the phylogenetic position of Zschokkella auritis within Thelohanellus clade clustered with Myxobolous cuttacki was supported with low bootstrap value. These Zschokkella spp. may be sister taxa to Myxobolus spp. or they may be Myxobolus species.

This study suggested that morphological characters are significant for the taxonomy of myxosporea as the 
Gupta, A. et al. / J. Appl. \& Nat. Sci. 13(1): 51 - 58 (2021)

Table 1. List of Indian species of Myxosporean parasites with their host, location and accession numbers.

\begin{tabular}{|c|c|c|c|c|}
\hline Myxosporean species & Authors and Year & Host & Location & Accession number \\
\hline Myxobolus bengalensis & Abraham et al. $2014^{*}$ & Catla catla & West Bengal & KJ476883, MK412934 \\
\hline Myxobolus rocatlae & Abraham et al. 2014* & Catla catla & West Bengal & KJ476878 \\
\hline Myxobolus ticto & Abraham et al. $2014^{*}$ & Puntius ticto & West Bengal & KJ476887 \\
\hline Thelohanellus catlae & Abraham et al. 2014* & Catla catla & West Bengal & KJ476881, KJ476882 \\
\hline Thelohanellus rohita & Abraham et al. 2014* & Labeo rohita & West Bengal & $\begin{array}{l}\text { KF170927, KF170926 } \\
\text { MK412940 }\end{array}$ \\
\hline $\begin{array}{l}\text { Thelohanellus habibpuri } \\
\text { Thelohanellus jiroveci } \\
\text { Thelohanellus seni }\end{array}$ & $\begin{array}{l}\text { Abraham et al. 2014* } \\
\text { Abraham et al. 2014* } \\
\text { Abraham et al. } 2014^{*}\end{array}$ & $\begin{array}{l}\text { Labeo rohita } \\
\text { Labeo rohita } \\
\text { Labeo rohita }\end{array}$ & $\begin{array}{l}\text { West Bengal } \\
\text { West Bengal } \\
\text { West Bengal }\end{array}$ & $\begin{array}{l}\text { KM252683, KM252681 } \\
\text { KJ476885 } \\
\text { KJ476884 }\end{array}$ \\
\hline Myxobolus cuttacki & Rajesh et al. 2014 & Labeo bata & West Bengal & KF465682 \\
\hline $\begin{array}{l}\text { Thelohanellus filli } \\
\text { Thelohanellus caudatus }\end{array}$ & $\begin{array}{l}\text { Kaur et al. } 2014 \\
\text { Anjan et al. } 2014\end{array}$ & $\begin{array}{l}\text { Labeo rohita } \\
\text { Labeo rohita }\end{array}$ & $\begin{array}{l}\text { Punjab } \\
\text { West Bengal }\end{array}$ & $\begin{array}{l}\text { KR340464 } \\
\text { KJ476877, MK412941 }\end{array}$ \\
\hline Myxobolus auratus & Banerjee et al. $2015^{*}$ & Carassius auratus & West Bengal & KX399851 \\
\hline Henneguya bicaudi & Kaur and Attri 2015 & Cirrhinus mrigal & Punjab & KP099967 \\
\hline Myxobolus arcticus & Abidi et al. 2015 & Clarius batachus & Uttar Pradesh & KF662475 \\
\hline Myxobolus basuhaldari & Szekely et al. 2015 & $\begin{array}{l}\text { Catla catla/Labeo } \\
\text { rohita }\end{array}$ & Uttar Pradesh & $\begin{array}{l}\text { KM029976, KM029974, } \\
\text { KM029975 }\end{array}$ \\
\hline Myxobolus bhadrensis & Szekely et al. 2015 & $\begin{array}{l}\text { Labeo rohita / Catla } \\
\text { catla }\end{array}$ & Uttar Pradesh & $\begin{array}{l}\text { KM029970, KM029971, } \\
\text { KM029968, KM029969, } \\
\text { KM029972 }\end{array}$ \\
\hline Thelohanellus qadrii & Banerjee et al. 2015a & $\begin{array}{l}\text { Amblypharyngodon } \\
\text { mola }\end{array}$ & West Bengal & KF170928, MK412939 \\
\hline Myxobolus carnaticus & Banerjee et al. 2015b & Cirrhinus mrigala & West Bengal & KF796620 \\
\hline Myxobolus catlae & Szekely et al. 2015 & Cirrhinus cirrhosis & Uttar Pradesh & KM029967, KR819276 \\
\hline Myxobolus cerebralis & Abidi et al. 2015 & Cyprinus carpio & Uttar Pradesh & KM671790, KJ701267 \\
\hline Myxobolus kalavatiae & Szekely et al. 2015 & Cirrhinus cirrhosis & Uttar Pradesh & KM029973 \\
\hline Myxobolus meerutensis & Szekely et al. 2015 & Labeo rohita & Uttar Pradesh & KM029977 \\
\hline Myxobolus orissae & Abraham et al. 2015 & Cirrhinus mrigala & West Bengal & KF448527 \\
\hline Myxobolus catli & Abraham et al. 2016* & Catla catla & West Bengal & KR819272 \\
\hline Myxobolus mrigalhitae & Abraham et al. 2016* & Catla catla & West Bengal & $\begin{array}{l}\text { KJ476880, KJ476879 } \\
\text { KR819275 }\end{array}$ \\
\hline $\begin{array}{l}\text { Thelohanellus andhrae } \\
\text { Thelohanellus bifurcate }\end{array}$ & $\begin{array}{l}\text { Abraham et al. 2016* } \\
\text { Abraham et al. 2016* }\end{array}$ & $\begin{array}{l}\text { Labeo rohita } \\
\text { Labeo rohita }\end{array}$ & $\begin{array}{l}\text { West Bengal } \\
\text { West Bengal }\end{array}$ & $\begin{array}{l}\text { KR819270 } \\
\text { KJ476886, KR819274 }\end{array}$ \\
\hline Ceratomyxa collarae & Sanil et al. 2017 & Chaetodon collare & Kerala & $\begin{array}{l}\text { KU726595, KU726593, } \\
\text { KU726592 }\end{array}$ \\
\hline $\begin{array}{l}\text { Ceratomyxa leucoster- } \\
\text { noni }\end{array}$ & Sanil et al. 2017 & $\begin{array}{l}\text { Acanthurus leu- } \\
\text { costernon }\end{array}$ & Kerala & KU726596 \\
\hline Henneguya chaudhuryi & Chaudhary et al. 2017 & Channa punctata & Uttar Pradesh & KT279402 \\
\hline Myxobolus catmrigalae & Banerjee et al. 2017 & Cirhinus mrigal & West Bengal & KC933944 \\
\hline Thelohanellus boggoti & Kaur and Gupta 2017a & Labeo dero & Punjab & KU884967 \\
\hline Thelohanellus muscularis & Kaur and Gupta 2017b & Catla catla & Punjab & KT387308 \\
\hline Thelohanellus theinensis & Gupta and Kaur 2017 & Labeo bata & Punjab & KP792568 \\
\hline Zschokkella auratis & Paul et al. $2017^{*}$ & Channa striata & Odisha & MF978273 \\
\hline Chloromyxum argusi & Chandran et al. 2018 & Scatophagus argus & Kerala & MG029441, MG029440 \\
\hline Myxobolus ompok & Chaudhary et al. 2018 & Ompok pabda & Uttar Pradesh & MG760574, MG760575 \\
\hline Thelohanellus wallagoi & Gupta et al. 2018 & Wallago attu & Uttar Pradesh & $\begin{array}{l}\text { MG099779, MG099781, } \\
\text { MG099782 }\end{array}$ \\
\hline Henneguya mystasi & Chaudhary et al. 2019 & Mystus vittatus & Uttar Pradesh & МH300136 \\
\hline Myxobolus cylindricus & Chaudhary et al. 2019 & Channa gachua & Uttar Pradesh & MH424126 \\
\hline Myxobolus toyamai & Fariya et al. 2020 & Cyprinus carpio & Uttar Pradesh & MG800830 \\
\hline Ortholinea scatophagi & Chandran et al. 2020 & Scatophagus argus & Kerala & MN310514 \\
\hline
\end{tabular}

*Shows as unpublished sequences on NCBI. 


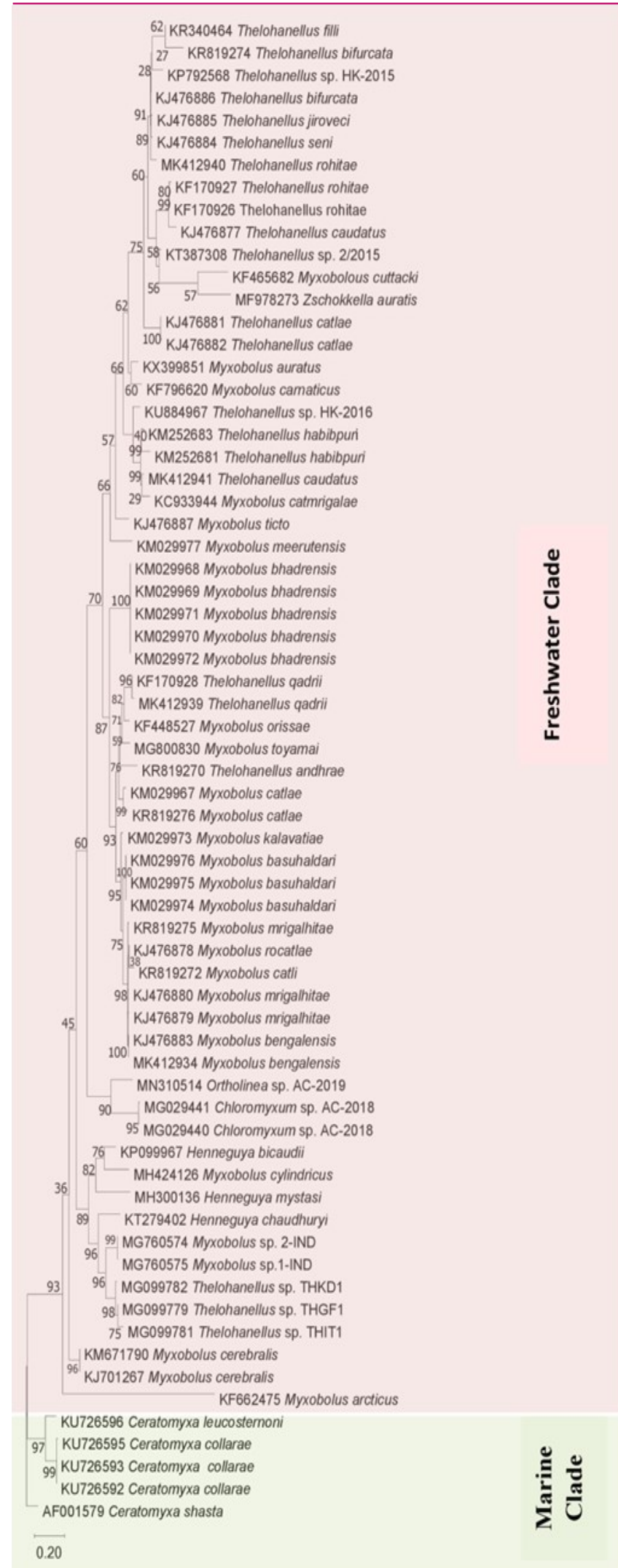

Fig. 1. Maximum likelihood phylogenetic tree based on SSU rDNA sequences of all myxosporean species available in NCBI database from India. Ceratomyxa shasta is as outgroup species. Numbers at nodes indicate ML bootstrap values (1000 replications). The scale bar indicates the number of substitution per site. clades showed the affinity to tissue tropism and present findings corroborate with previous studies that tissue tropism is an important factor that should be considered for myxozoan phylogenetic studies (Molnár, 1994). Several studies were conducted on the basis of phylogenetic analysis and many revisions of myxozoan taxonomy were done (Smothers et al., 1994; Palenzuela et al., 2002; Whipps et al., 2004; Jirku et al., 2007; Heiniger et al., 2011). Molecular data have largely driven and showed incremental improvement of myxozoan classification system. As the sequencing become more common, resulting more sequences available, more revisions can be proposed with the help of more precise studies of phylogenies of myxozoan. The genus Myxobolus is paraphyletic and difficult to distinguish from Zschokkella, in such conditions molecular data along with the distinctive morphological characters might be used as guiding tool. The polyphyly of Choloromyxum is now well recognized and several clarifications have been made between this and other genera using molecular phylogenies reassigning other species too and from this group (Gunter and Adlard, 2010). Therefore, it is demonstrated that molecular data are likely to be necessary for myxozoan classification and many species descriptions should be obtained for discriminating or describing myxozoans related to these problematic taxa. Regardless of the increasing number of available SSU rDNA sequences, the proportion of sequenced species is low and many species are still unknown to science. The finding of the present study does not correspond between SSU rDNA phylogeny and current taxonomy. The present study revealed paraphyletic and polyphyletic genera within myxosporeans. Other genes should also be incorporated whether SSU rDNA phylogeny corresponds to organismal phylogeny. The combined analysis of appropriate genes could also increase the resolution of myxosporean phylogeny.

\section{Conclusion}

Parasites substantially play fundamental ecological and evolutionary roles and also contribute to biodiversity. Existing knowledge on the myxosporean on molecular taxonomy is incomplete in India because most of the taxa have been described on the basis of traditional spore-based taxonomy. Molecular data helps in testing the morphological results and provide independent evidence relevant for a classification system based on phylogenetic analysis. Careful consideration is needed in selecting more useful molecular marker for the systematics of myxosporeans. The increasing number of rDNA data on myxosporean species demonstrated the existence of conflicting signals within the phylogenomic dataset. The use of molecular studies in addition to 
morphological characters, will be very useful for subsequent workers to understand the gaps in myxozoan diversity and their taxonomy. Additional taxon sequencing is needed for certain genera e,g, Zschokkella, Chloromyxum, Ortholinea from Indian subcontinent for which few of species have been sequenced. Therefore, re-investigation of the traditional spore-based myxozoan taxonomy with the help of markers like SSU and LSU rDNA to address persisting taxonomic and phylogenetic discrepancies of this highly divergent taxa and also to facilitate the development of novel strategies to effectively prevent and control disease outbreaks and their economic impacts.

\section{ACKNOWLEDGEMENTS}

The authors are thankful to Head, Department of Zoology, Chaudhary Charan Singh University, Meerut, Uttar Pradesh, India, for providing laboratory facilities.

\section{Conflict of interest}

The authors declare that they have no conflict of interest.

\section{REFERENCES}

1. Abdel-Gaber, R., Abdel-Ghaffar, F., Maher, S., El-Mallah, A. M., Al Quraishy, S., \& Mehlhorn, H. (2017). Morphological re-description and phylogenetic relationship of five myxosporean species of the family Myxobolidae infecting Nile tilapia. Dis. Aquat. Org., 124, 201-214. https://doi.or $\mathrm{g} / 10.3354 / \mathrm{da0} 03118$

2. Abidi, R., Fariya, N. \& Chauhan, U. K. (2015). Development and standardization of PCR technique to detect myxozoan parasites and its use in identification of two exotic Myxobolus species from Indian catfish Clarias batrachus (linn.). Int. J. Fish. Aquat. Stud., 2, 374-377.

3. Abraham, T. J., Banerjee, S., Patra, A., Sarkar, A., Adikesavalu, H., \& Dash, G. (2015). Molecular phylogeny of Myxobolus orissae (Myxosporea: Myxobolidae) infecting the gill lamellae of mrigal carp Cirrhinus mrigala (Actinopterygii: Cyprinidae). Mol. Biol. Res. Commun., 4, 15-24.

4. Andree, K. B., Székely, C., Molnár, K., Gresoviac, S. J., \& Hedrick, R. P. (1999). Relationships among members of the genus Myxobolus (Myxozoa: Bilvalvidae) based on small subunit ribosomal DNA sequences. J. Parasitol., 85, 68-74. https://doi.org/10.2307/3285702

5. Anjan, M., Sayani, B., Avijit, P., Harresh, A., Raghu, R. K., Gadadhar, D. and Jawahar, A. T. (2014). Molecular \& morphometric characterization of Thelohanellus caudatus (Myxosporea: Myxobolidae) infecting the caudal fin of Labeo rohita (Hamilton). Protistol., 8, 41-52.

6. Banerjee, S., Patra, A., Adikesavalu, H., Joardar, S. N. \& Abraham, T. J. (2015a). Molecular and phylogenetic characterization of Thelohanellus qadrii (Myxozoa, Myxosporea, Bivalvulida) infecting the secondary gill epithelium of Indian major carp, Catla catla (Hamilton, 1822). Mol. Biol. Res. Commun., 4, 83-91.
7. Banerjee, S., Patra, A., Adikesavalu, H., Mondal, A. \& Abraham, T. J. (2015b). The phylogenetic position of Myxobolus carnaticus (Myxozoa, Myxosporea, Bivalvulida) infecting gill lamellae of Cirrhinus mrigala (Hamilton, 1822) based on $18 \mathrm{~S}$ rRNA sequence analysis. Mol. Biol. Res. Commun., 4, 125-132.

8. Banerjee, S., Patra, A., Mondal, A., Adikesavalu, H., Ramudu, K. R., Dash, G. and Abraham, T. J. (2017). Molecular characterization of Myxobolus catmrigalae (Myxosporea: Myxobolidae) infecting the gill lamellae of carp Cirrhinus mrigala (Hamilton). J. Parasit. Dis. 41, 6270 .

9. Bartošová, P., Fiala, I., \& Hypša, V. (2009). Concatenated SSU and LSU rDNA data confirm the main evolutionary trends within myxosporeans (Myxozoa: Myxosporea) and provide an effective tool for their molecular phylogenetics. Mol. Phylogenet. Evol., 53, 81-93. https:// doi.org/10.1016/j.ympev.2009.05.018

10. Bartošová, P., Fiala, I., Jirků, M., Cinková, M., Caffara, M., Fioravanti, M. L., \& Holzer, A. S. (2013). Sphaerospora sensu stricto: taxonomy, diversity and evolution of a unique lineage of myxosporeans (Myxozoa). Mol. Phylogenet. Evol., 68, 93-105. https://doi.org/10.1016/ j.ympev.2013.02.026

11. Chandran, A., Zacharia, P. U. \& Sanil, N. K. (2020). Ortholinea scatophagi (Myxosporea: Ortholineidae), a novel myxosporean infecting the spotted scat, Scatophagus argus (Linnaeus 1766) from southwest coast of India. Parasitol. Int., 75, 102020. https://doi.org/10.1016/ j.parint.2019.102020

12. Chandran, A., Zacharia, P. U., Sathianandan, T. V., Shamal, P., Binesh, C. P., Kaur, P. \& Sanil, N. K. (2018). Morphological and molecular characterization of Chloromyxum argusi n. sp. (Myxosporea) infecting the urinary bladder of Scatophagus argus Linnaeus 1766 (Scatophagidae) from the southwest coast of India. Parasitol. Res., 117, 31453156. https://doi.org/10.1007/s00436-018-6013-5

13. Chaudhary, A., Goswami, U., Gupta, A., Cech, G., Singh, H. S., Molnár, K., Szekely, C. \& Sharma, B. (2018). Morphological, histological, and molecular description of $M y x-$ obolus ompok n. sp. (Myxosporea: Myxobolidae), a kidney myxozoan from Pabdah catfish Ompok pabda (Hamilton, 1822) (Siluriformes: Siluridae) in India. Parasitol. Res., 117, 1899-1905. https://doi.org/10.1007/s0 0436-018 $-5882-y$

14. Chaudhary, A., Gupta, A., Goswami, U., Cech, G., Molnár, K., Singh, H. S. \& Székely, C. (2019). Molecular Genetic Studies on Myxobolus cylindricus and Henneguya mystasi (Myxosporea: Myxobolidae) Infecting Two Indian Fish Species, Channa gachua and Mystus vittatus, Respectively. Acta Parasitol., 64, 129-137. https://doi.org/10.2478/ s11686-018-00014-8

15. Chaudhary, A., Molnár, K., Gupta, A., Cech, G., Singh, H. S. \& Székely, C. (2017). Redescription of Henneguya chaudhuryi (Bajpai \& Haldar, 1982) (Myxosporea: Myxobolidae), infecting the gills of the freshwater fish Channa punctata (Bloch) (Perciformes: Channidae) in India. Syst. Parasitol., 94, 403-411. https://doi.org/10.1007/s11230017-9705-9

16. Evans, N. M., Holder, M. T., Barbeitos, M. S., Okamura, B., and Cartwright, P. (2010). The phylogenetic position of Myxozoa: exploring conflicting signals in phylogenomic 
and ribosomal data sets. Mol. Biol. Evol., 27, 2733-2746. https://doi.org/10.1093/molbev/msq159

17. Fariya, N., Ali, D., Abide, R., Falodah, F. A., Alarifi, S. \& Alkahtani, S. (2020). Morphological and molecular evidence for Myxobolus toyami as an evolutionary link between Thelohanellus and Myxobolus genera of myxozoan parasites. Fresenius. Environ. Bull., 29, 633-639.

18. Fiala, I. (2006). The phylogeny of Myxosporea (Myxozoa) based on small subunit ribosomal RNA gene analysis. Int. J. Parasitol., 36, 1521-1534. https://doi.org/10.1016/ j.ijpara.2006.06.016

19. Fiala, I. \& Bartošová, P. (2010). History of myxozoan character evolution on the basis of rDNA and EF-2 data. BMC Evol. Biol., 10, 228-235. https://doi.org/10.1186/14712148-10-228

20. Fiala, I., Bartošová-Sojková, P., Okamura, B., \& Hartikainen, H. (2015). Adaptive radiation and evolution within the Myxozoa. In Myxozoan evolution, ecology and development, pp 69-84. https://doi.org/10.1007/978-3-319 $-14753-6 \_4$

21. Jirku, M., Fiala, I., \& Modrý, D. (2007). Tracing the genus Sphaerospora: rediscovery, redescription and phylogeny of the Sphaerospora ranae (Morelle, 1929) n. comb. (Myxosporea, Sphaerosporidae), with emendation of the genus Sphaerospora. Parasitology, 134, 1727-1739. https://doi.org/10.1017/s0031182007003241

22. Gunter, N., \& Adlard, R. (2010). The demise of Leptotheca Thélohan, 1895 (Myxozoa: Myxosporea: Ceratomyxidae) and assignment of its species to Ceratomyxa Thélohan, 1892 (Myxosporea: Ceratomyxidae), Ellipsomyxa Køie, 2003 (Myxosporea: Ceratomyxidae), Myxobolus Bütschli, 1882 and Sphaerospora Thélohan, 1892 (Myxosporea: Sphaerosporidae). Syst. Parasitol 75, 81-104. https:// doi.org/10.1007/s11230-009-9227-1

23. Gupta, A. \& Kaur, H. (2017). Morphological, histopathological and molecular characterization of Thelohanellus theinensis n. sp. (Cnidaria: Myxosporea) infecting an Indian major carp, Labeo bata in a cold water wetland in Punjab (India). J. Parasit. Dis., 41, 629-638. https:// doi.org/10.1007/s12639-016-0856-4

24. Gupta, A., Chaudhary, A., Garg, A., Verma, C., Singh, H. S. \& Sharma, B. (2018). First molecular evidence of Thelohanellus wallagoi Sarkar, 1985 (Myxozoa) from economically important food fish, freshwater shark Wallago attu (Siluridae) in India. Acta Parasitol., 63, 647-653. https://doi.org/10.1515/ap-2018-0075

25. Heiniger, H., Gunter, N. L., \& D ADLARD, R. O. B. E. R. T. (2011). Re-establishment of the family Coccomyxidae and description of five novel species of Auerbachia and Coccomyxa (Myxosporea: Bivalvulida) parasites from Australian fishes. Parasitology, 138, 501-515. https:// doi.org/10.1017/s0031182010001447

26. Hartikainen, H., Gruhl, A., \& Okamura, B. (2014). Diversification and repeated morphological transitions in endoparasitic cnidarians (Myxozoa: Malacosporea). Mol. Phylogenet. Evol., 76, 261-269.https://doi.org/10.1016/j.ympev.20 14.03.010

27. Holzer, A. S., Sommerville, C., \& Wootten, R. (2004). Molecular relationships and phylogeny in a community of myxosporeans and actinosporeans based on their $18 \mathrm{~S}$ rDNA sequences. Int. J. Parasitol., 34,1099-1111.https:// doi.org/10.1016/j.jpara.2 004.06.002
28. Kalavati, C. \& Nandi, N. C. (2007). Handbook on myxosporean parasites of Indian fishes. New Delhi: Zoological Survey of India, Kolkata, India, pp-294.

29. Kaur, H. (2014). Myxozoan infestation in freshwater fishes in wetlands and aquaculture in Punjab (India). Adv. Anim. Vet. Sci., 2, 488-502. https://doi.org/10.14737/ journal.aavs/2014/2.9.488.502

30. Kaur, H. \& Attri, R. (2015). Morphological and molecular characterization of Henneguya bicaudi n. sp.(Myxosporea: Myxobolidae) infecting gills of Cirrhinus mrigala (Ham.) in Harike Wetland, Punja (India). Parasitol. Res., 114, 41614167. https://doi. org/10.1007/s00436-015-4647-0

31. Kaur, H. \& Gupta, A. (2017a). Molecular and phylogenetic characterization of Thelohanellus boggoti Qadri, 1962 (Cnidaria, Myxosporea, Bivalvulida) infecting the fin of Indian minor carp Labeo dero (Hamilton, 1822). Mol. Biol. Res. Commun., 6, 13-21.

32. Kaur, H. \& Gupta, A. (2017b). Morphological, histopathological and molecular characterization of Thelohanellus muscularis n. sp. (Cnidaria: Myxosporea) infecting head muscles of Labeo rohita from Ranjit sagar wetland, Punjab (India). J. Appl. Bio. Biotechnol., 5, 21-28. https:// doi.org/10.7324/jabb.2 017.50104

33. Kaur, H. \& Singh, R. (2012). A synopsis of the species of Myxobolus Bütschli, 1882 (Myxozoa: Bivalvulida) parasitizing Indian fishes and a revised dichotomous key to myxosporean genera. Syst. Parasitol., 81, 17-37. https:// doi.org/10.1007/s11230-011-9321-z

34. Kaur, H., Katoch, A. \& Gupta, M. (2014). Thelohanellus filli sp. n., a pathogenic myxosporean infecting gills of cultured carp, Labeo rohita (Hamilton 1822) in Punjab, India. Species, 10, 31-38.

35. Kent, M. L., Andree, K. B., Bartholomew, J. L., ElMatbouli, M., Desser, S. S., Devlin, R. H. \& Hallett, S. L. (2001). Recent advances in our knowledge of the Myxozoa. J. Eukaryot. Microbiol., 48, 395-413. https:// doi.org/10.1111/j.1550-7408.2001.tb00173.x

36. Kosakyan, A., Alama-Bermejo, G., Bartošová-Sojková, P., Born-Torrijos, A., Šíma, R., Nenarokova, A. \& Holzer, A. S. (2019). Selection of suitable reference genes for gene expression studies in myxosporean (Myxozoa, Cnidaria) parasites. Sci. Rep., 9, 1-14. https://doi.org/10.1038/ s41598-019-51479-0

37. Kumar, S., Stecher, G., Li, M., Knyaz, C., \& Tamura, K. (2018). MEGA X: molecular evolutionary genetics analysis across computing platforms. Mol. Biol. Evol., 35, 15471549. https://doi.org/10.1093/molbev/msy096

38. Lom, J. \& Dyková, I. (2006). Myxozoan genera: definition and notes on taxonomy, life-cycle terminology and pathogenic species. Folia Parasitol., 53, 1-36. https:// doi.org/10.14411/fp.2006.001

39. Molnár, K. (1994). Comments on the host, organ and tissue specificity of fish myxosporeans and on the types of their intrapiscine development. Parasitol. Hung., 27, 5-20.

40. Naldoni, J., Maia, A. A., Correa, L. L., da Silva, M. R., \& Adriano, E. A. (2018). New myxosporeans parasitizing Phractocephalus hemioliopterus from Brazil: morphology, ultrastructure and SSU-rDNA sequencing. Diseases of aquatic organisms, 128(1), 37-49. https://doi.org/10.3354/ dao03210

41. Palenzuela, O., Redondo, M. J., \& Alvarez-Pellitero, $P$. (2002). Description of Enteromyxum scophthalmi gen. 
nov., sp. nov. (Myxozoa), an intestinal parasite of turbot (Scophthalmus maximus L.) using morphological and ribosomal RNA sequence data. Parasitol., 124, 369-379. https://doi.org/10.1017/s0031182001001354

42. Rajesh, S. C., Banerjee, S., Patra, A., Dash, G., \& Abraham, T. J. (2014). Molecular characterization of Myxobolus cuttacki (Myxozoa, Myxosporea, Bivalvulida) infecting gill lamellae of minor carp Labeo bata (Ham.). Mol. Biol. Res. Commun., 3, 231-239.

43. Sanil, N. K., Chandran, A., Shamal, P. \& Binesh, C. P. (2017). Molecular and morphological descriptions of Ceratomyxa collarae n. sp. and Ceratomyxa leucosternoni $\mathrm{n}$. sp. from marine ornamental fishes of Indian waters. Parasitol. Res., 116, 529-537. https:// doi.org/10.1007/s00436-016-5317-6

44. Saulnier, D., Philippe, H., \& Kinkelin, P. (1999). Molecular evidence that the proliferative kidney disease organism unknown (PKX) is a myxosporean. Dis. Aquat. Org., 36, 209-212. https://doi.org/10.3354/dao036209

45. Singh, R. \& Kaur, H. (2012). Biodiversity of myxozoan parasites infecting freshwater fishes of three main wetlands of Punjab, India. Protistol., 7, 79-89.

46. Smothers, J. F., Von Dohlen, C. D., Smith, L. J., \& Spall, R. D. (1994). Molecular evidence that the myxozoan protists are metazoans. Science, 265, 1719-1721. https:// doi.org/10.1126/science. 8085160

47. Székely, C., Cech, G., Chaudhary, A., Borzák, R., Singh, H. S. \& Molnár, K. (2015). Myxozoan infections of the three Indian major carps in fish ponds around Meerut, UP, India, with descriptions of three new species, Myxobolus basuhaldari sp. n., M. kalavatiae sp. n. and M. meerutensis sp. n., and the redescription of $M$. catlae and $M$. bhadrensis. Parasitol. Res., 114, 1301-1311. DOI:10.10 07/s00436-014-4307-9

48. Whipps, C. M., \& Kent, M. L. (2006). Phylogeography of the cosmopolitan marine parasite Kudoa thyrsites (Myxozoa: Myxosporea). J. Eukaryot. Microbiol., 53, 364373. https://doi.org/10.1111/j.1550-7408.2006.00114.x

49. Whipps, C. M., Grossel, G., Adlard, R. D., Yokoyama, H., Bryant, M. S., Munday, B. L., \& Kent, M. L. (2004). Phylogeny of the Multivalvulidae (Myxozoa: Myxosporea) based on comparative ribosomal DNA sequence analysis. J. Parasitol., 90, 618-622. https://doi.org/10.1645/ge$153 r$

50. Ye, L., Lu, M., Quan, K., Li, W., Zou, H., Wu, S., \& Wang, G. (2017). Intestinal disease of scattered mirror carp Cyprinus carpio caused by Thelohanellus kitauei and notes on the morphology and phylogeny of the myxosporean from Sichuan Province, southwest China. Chin. J. Oceanol. Limn., 35, 587-596. https://doi.org/10.1007/ s00343-017-5312-5

51. Zhao, Y. J., Li, N. N., Tang, F. H., \& Dong, J. L. (2013). Remarks on the validity of Myxobolus ampullicapsulatus and Myxobolus honghuensis (Myxozoa: Myxosporea) based on SSU rDNA sequences. Parasitol. Res., 112, 3817-3823. https://doi.org/10.1007/s00436-013-3569-y 